\begin{tabular}{lrr} 
STUDIA & ROMANICA & POSNANIENSIA \\
\hline UAM & Vol. 41/2 & Poznań 2014
\end{tabular}

JUSTYNA TEODOROWICZ

jus@amu.edu.pl

Uniwersytet im. Adama Mickiewicza, Poznań

\title{
MOTIVUL MUZICII ȘI AL MĂRII ÎN PROZA LUI ANTON HOLBAN
}

\begin{abstract}
Justyna Teodorowicz, Motivul muzicii şi al mării în proza lui Anton Holban [The motif of music and of the sea in Anton Holban's prose], Studia Romanica Posnaniensia, Adam Mickiewicz University Press, Poznań, vol. XLI/2: 2014, pp. 109-114. ISBN 978-83-232-2703-8. ISSN 0137-2475. eISSN 2084-4158. DOI: 10.7169/strop2014.412.009
\end{abstract}

The purpose of the present article is to discuss two literary motifs that can be traced throughout Anton Holban's prose works: music and the sea. Holban, who wrote also music reviews for newspapers, had a genuine passion for music, which is reflected in his novels and short stories. Music appears in Holban's literature as the highest form of artistic expression, and, at the same time, as a special and unique code used by lovers to communicate with each other, which isolates them from other people. Music seems to be more important than a relationship with a woman and even than literary creation. It may become an obsession. Listening to music in solitude gives the narrator an opportunity to explore his inner world and to be himself. The sea means much more than a landscape in Holban's works. Like music, it has a symbolic dimension, being for the protagonists a source of extatic, almost mistic experience, as well as a witness to their deepest and most intimate feelings. From philosophical point of view, the sea means infinity, eternal movement and perfection.

Keywords: music, sea, passion, symbol, code, perfection, Anton Holban

Într-un dicţionar de scriitori români Alexandru Călinescu îl caracterizează astfel pe Anton Holban: „Temperamental, [...] era un romantic: un romantic prin obsesia singurătăţii, a morţii, prin vocaţia nefericirii [...]" (Călinescu, 1978). La trăsăturile creaţiei holbaniene enumerate de critic, care justifică această etichetă, am adăuga şi importanţa deosebită acordată de către prozator muzicii şi mării ca factori esenţiali pentru păstrarea integrităţii ființei sale.

Anton Holban, autor a numeroase articole despre muzică (între anii 1932 și 1934 colaborează la ziarul Vremea semnând cronica muzicală), îşi exprimă frecvent fascinaţia pentru această ramură a artei. În Pseudojurnal scriitorul declară:

Muzica reprezintă pasiunea mea cea mai profundă. Un concert mă face să uit toate necazurile şi singura mea preocupare este viitorul concert al lui Thibaut. Sunt foarte mîndru de discoteca mea. Cîteodată mă surprinde dimineața schimbînd plăcile. Am Missa în si a lui Bach în şaptesprezece plăci. Ce orgie, pentru cîteva ceasuri! (Holban, 1978: 215). 
Muzica pare a fi pentru prozator mai importantă decât creaţia sa literară. Într-un interviu din 1934 Holban mărturiseşte: „Se vede că nu sunt un om de litere înnăscut, căci dacă aş avea o ocazie de a pleca la capătul lumii, sau de a asculta tot timpul muzică, n-aş mai scrie un rând [...]" (Alimăneşteanu, 1934).

Pasiunea scriitorului îşi găseşte reflectarea în opera lui. Muzica pătrunde în toată proza lui Anton Holban, atât în nuvele, cât şi în romane, jucând pentru personaje, după cum observă Ion Simuţ, rolul unei ,,probe decisive de existenţă, inteligenţă şi sensibilitate" (Simuţ, 2006). În nuvela Colecţionarul de sunete scriitorul evocă momentele cele mai importante legate de iniţierea sa muzicală. Citim aici despre „faptele de bravură” (Holban, 1958: 312) ale tânărului meloman, care reuşeşte să intre la Ateneu fără bilet pentru a aştepta ceasuri întregi, ascuns, începutul concertului. În altă parte sunt amintite patefonul, „tovarăşul tuturor singurătăţilor şi al nopţilor de veghe" (Holban, 1958: 313), şi colecţia preţioasă de discuri, fiecare având istoria lui. $\mathrm{Cu}$ aceeași personificare a acestor obiecte, rezultând din pasiunea obsesională pentru muzică, avem de-a face şi în nuvela Halucinaţii:

Şi dacă îți place muzica atît de mult că te obsedează meandrele ei ziua şi noaptea; că porţi cu tine, întotdeauna, oricît ai părea de preocupat în altă parte, o temă de cîteva note; că începi să asculţi şi deodată bagi de seamă că au trecut cîteva ore fără să le observi, iar a doua zi începi din nou; atunci patefonul tău... îşi pierde rigiditatea, lemnul prinde căldură, iar înăuntrul lui ai impresia că auzi pulsaţia. Şi plăcile, fiinţe veritabile, identice şi totuşi fiecare cu viaţa ei interioară, pe care trebuie să te înveţi s-o cunoşti, să-i pricepi subtilitatea detaliului şi în acelaşi timp personalitatea; să le iubeşti cu pasiune, să te consolezi şi să le înşeli una cu alta şi apoi iar să revii. Căci fiecare şi-a împlîntat în tine cîte o emoţie, căreia îi vei rămîne fidel (Holban, 1958: 363-364).

În romanele lui Holban muzica apare ca cea mai înaltă dintre toate formele artei care provoacă stări de extaz, trăiri aproape mistice. Pentru Sandu, alter-ego al scriitorului, ea constituie „o sursă de fericire inepuizabilă”, un „paradis” regăsit, un „narcotic preţios” pe care îl are „la dispoziţie pentru necazuri” (Holban, 1971a: 119).

Alături de mare, muzica este şi un martor al dramei naratorului romanelor holbaniene. Cele şaptesprezece discuri ale Missei lui Bach sunt ascultate de nenumerate ori de către Sandu pe vremea când Irina îl înşală, iar andantele funebru al Cvintetului lui César Frank îl însoțeşte după ce primește vestea despre moartea amantei. Totodată, în momentele cele mai dificile, muzica îl ajută pe eroul lui Holban să învingă toate vicisitudinile. Este pentru el un refugiu, spaţiul unde Sandu coboară în adâncurile sufletului său, devenind el însuşi: ,,[...] profitam de muzică” spune protagonistul - ,pentru că mă puteam retrage în mine, pentru a nu mi se mai părea că ceea ce-mi este mai intim a fost invadat de un străin" (Holban, 1971a: 157). 
Pasiunea pentru muzică capătă, uneori, dimensiuni surprinzătoare, devine chiar tiranică. Emoţia „artistică” tinde să se substituie trăirilor autentice, întrucât muzica îi oferă eroului o varietate a experienţelor psihice pe care nu o poate găsi în alte domenii ale vieţii. În romanul $O$ moarte care nu dovedeşte nimic Sandu apreciază plăcerile auditive mai mult decât momentele de extaz erotic alături de Irina: „,N-a avut amorul nici o practică pe care Irina să n-o cunoască şi la care să nu se preteze. [...] Dar cu toate momentele acestea ascuţite, n-aş fi renunţat pentru ele la vreun bilet de concert" (Holban, 1971a: 60).

În Ioana, de asemenea, naratorul îi preferă amantei sale „o fiinţă nouă, muzica”, în care găseşte ,singurele consolări” (Holban, 1971a: 157). Eroul holbanian este convins că plăcerile legate de muzică se pot savura numai în solitudine: „Odată [...] am venit la ea cu brațele pline de flori, cărţi, discuri. Discuri multe, întreaga Missa in si a lui Bach. Mai tîrziu avea remuşcări că întîrzia să mi le înapoieze, dar nu cred să le fi cîntat pe toate. Pentru aşa ceva trebuie să trăieşti în singurătate şi să nu fii întreruptă la fiecare moment de oameni surzi pentru muzică [...]" (Holban, 1971b: 42).

Pe de altă parte, muzica este un mijloc perfect de comunicare între amanţi, mai eficace decât cuvintele. Eroul romanului Jocurile Daniei îi propune iubitei sale: „Cînd nu ne vom mai vedea, [...] vino la un concert. Mă vei găsi cu siguranţă. Mă vei simţi fără să stai pe scaunul de alături” (Holban, 1971b: 42). Şi în altă parte: „,[...] Elisabeth Schumann a dat un concert la noi. Eram amîndoi în sală. La urmă s-a aplaudat, s-a cerut bis. Eram în grupul care aştepta în picioare să se mai cînte o bucată, iar Dania era lîngă mine. Şi Elisabeth Schumann a bisat Gute Nacht. Credeam că o astfel de întîmplare trebuia să ne lege pentru totdeauna [...]" (Holban, 1971b: 21).

Ideea unirii celor doi îndrăgostiţi prin muzică o găsim şi în romanul Ioana, unde Sandu observă: „În despărţirea noastră, Ioana, prin muzică, se simţea mai aproape de mine şi dacă din întîmplare [...] îi apărea vreo temă, cum ţi-ar ieşi o fiinţă încîntătoare pe neaşteptate, o floare într-un loc pustiu, atunci, uitînd toate urile, raţionamentele, convingerile, ar fi pornit cu orice risc la mine" (Holban, 1971a: 157-158).

Aşadar, muzica îi apropie pe eroi unul de celălalt izolându-i, totodată, de restul oamenilor. Descifrarea comună, notă cu notă, a partiturii unei opere wagneriene capătă dimensiuni simbolice, dând legăturii dintre Ioana şi Sandu un caracter cu totul excepţional. Datorită muzicii ei au un limbaj numai al lor. Înţelegerea acestei arte sublime, o veritabilă cunoaştere a ei îi sudează sufleţeşte, căci le formează şi le adânceşte simţurile. Nu s-ar iubi atât de mult, dacă n-ar exista în viaţa lor cărţile şi discurile, aduse în mansarda casei de la Cavarna. Wagner este deseori pomenit în creaţia holbaniană. Opera acestui compozitor Tristan şi Isolda este considerată de personaje o „operă la care vibrezi tot timpul, la cele mai mici detalii, şi apoi la 
îmbinarea lor măiastră, la delicateţea broderiei şi la efluviile blocului" (Holban, 1958: 361).

Holban vede în muzică o artă suverană prin limbajul ei universal şi capacitatea de a exprima în mod direct stările sufleteşti cele mai profunde. Pentru autorul unui roman psihologic exemplul muzicii este, desigur, captivant şi convingător.

Alături de muzică, proza lui Anton Holban este pătrunsă de contemplaţia marină. Naratorul romanelor şi al nuvelelor manifestă o sensibilitate deosebită faţă de mare ca simbol al mişcării eterne. Fiind un adevărat analist, dar şi un veritabil romantic, eroul holbanian consideră marea o oglindă în care se poate vedea pe el însuşi.

Personalitate de o maximă instabilitate, Holban compară mişcarea mării cu emoțiile sale complexe. Transformările de senzaţii se produc la el - cum spune scriitorul - „cu uşurinţa cu care valul se transformase din verde în albastru” (Holban, 1928b).

Deşi mişcarea îi pare un atribut al mării mai important decât culoarea, Holban este sensibil şi la cromatica marină. În romanul Ioana, armonizată cu peisajul sobru al Cavarnei şi fiind o reflectare a dramei cuplului, marea e „cenuşie, cu margini albe" (Holban, 1971a: 214). În schimb, Marea Nordului de pe coastele Normandiei are nuanţe extrem de bogate. Culoarea cenuşie este înlocuită cu „verdele-lăptos” care se preface ,,̂n albastru ce se termină cu făşii de scamă albă. Culorile curg şi nuanţele lor se îmbină în mişcare continuă", (Holban, 1928a) notează scriitorul.

Prezenţa mării în creaţia lui Holban are nu numai o valoare descriptivă, ci şi o dimensiune simbolică. $\mathrm{O}$ astfel de interpretare ne este sugerată de către scriitorul însuşi care, în romanul Ioana, subliniază uneori didactic participarea mării la frământările protagoniştilor: „Marea se zbate fără istovire ca şi sufletele noastre [...]” (Holban, 1971a: 109) sau în altă parte: „Gelozia şi dragostea mea se integraseră perfect cu legănarea mării, se complectau parcă" (Holban, 1971a: 258). Interesat mai ales de analiza proceselor interioare, Anton Holban nu ne oferă ample descrieri ale peisajului marin. Din impresiile notate concis rezultă o imagine a mării ca personaj-martor. Chiar de la începutul cărţii autorul face distincţie între o atitudine strict pragmatică faţă de mare, şi una spiritual-estetică. Pentru localnici „minunea” (Holban, 1971a: 119) desfăşurată în faţa lor înseamnă doar plăcerea de a face plajă sau posibilitatea de a mânca peşte, dar pentru Sandu marea răspunde dorinţei lui profunde de reflecţie, este cadrul unor drame trăite în solitudine: „Şi în ora cînd mă strecor printre cele cîteva corăbii ce odihnesc pe plaja mică şi mă ascund după o cotitură unde nu vin oameni de obicei, şi acolo mă întind pe nisip, cu marea şi cerul în faţa mea, şi urlu de disperare şi singurătate [...]" (Holban, 1971a: 156).

O plajă pustie este pentru Sandu şi un loc de defulare a tensiunii psihice pe care nu o poate împărtăşi cu alţii: „Cîteodată mă duc în lungul mării, pe unde nu vine 
nimeni, şi strig să întrec zgomotul valurilor: Ioana m-a înşelat! Fie-vă milă de mine!"' (Holban, 1971a: 257).

Marea este pentru protagonistul holbanian o sursă de emoţii unice, enivrante. În nuvela Halucinaţii citim:

Eram la mare. Şi acolo începeam, într-un timp pe care n-aş fi fost în stare să-l determin, aşa părea de capricios, plimbările în lungul apei. Cred că niciodată nu făceam în şir doi paşi asemănători, aşa eram de în voia capriciului culorilor şi zgomotului. Mă desfăceam, mi se topea fiinţa, plîngeam, mă zbăteam, mă cuprindeau doruri, gusturi de dans şi de moarte, chiar dacă pe faţă nu mi s-ar fi văzut mare lucru (Holban, 1958: 355).

Marea este o fiinţă atât de perfectă încât, în comparaţie cu prodigiosul spectacol al ei, mijloacele artei sunt cu totul insuficiente: ,[...] orice aş izbuti s-ar dărîma la prima apariție a apei. [...] Ar semăna construcția mea doar cît seamănă o păpuşă, avînd un mecanism izbutit, cu un om" (Holban, 1971a: 109). Marea sub lună, în special, este mult mai valoroasă decât „toate farmecile oferite de o creație omenească”, inclusiv „o carte genială, un oraş fantastic [...]” (Holban, 1971a: 119). Contemplată din punct de vedere filozofic, marea îi sugerează lui Sandu ideea nemărginirii, a infinitului, în comparaţie cu care fiinţa umană îi apare măruntă. Impresia maiestuozităţii se combină cu simţul sacrului: „Te porţi pios ca şi cum ai fi într-o biserică" (Holban, 1971a: 109).

Marea are un efect binefăcător asupra protagonistului care în prezenţa ei dobândește o stare de securitate: ,ai iluzia că poți să fii calm, că nici o nenorocire prea importantă nu se poate întîmpla" (Holban, 1971a: 109). Comparată cu marea, femeia nu poate oferi acelaşi calm: „Ce bicisnică, pornirea vijelioasă către o femeie!" (Holban, 1958: 355), exclamă naratorul. Astfel, Erosul cosmic simbolizat de mare este contrastat cu iubirea telurică a femeii.

Prezența constantă a motivului mării poate avea, cum sugerează Ofelia Ichim (Ichim, 2003: 210), şi alte semnificaţii, de la „proiecţia subconştientă a sentimentului matern" până la reprezentarea simbolică a vieţii şi a morţii.

Muzica şi marea au, pentru Anton Holban, nişte aspecte comune. Scriitorul descoperă în amândouă o frământare perpetuă, o combinaţie perfectă de sunete şi culori. Prestigiul lor rezultă, în opinia romancierului, din veşnica lor instabilitate, din fluiditatea lor splendidă care devine o metaforă a vieţii însăşi. Mai ales în romanul Ioana numeroase sunt scenele în care cele două „divinităţi” se reunesc. Marea este singurul decor potrivit pentru anumite compoziţii muzicale:

Uneori luam barca. [...] Luam cu noi patefonul, iar Ioana [...] punea mult timp aceeaşi placă. Am folosit mai ales Concertul al doilea pentru pian şi orchestră al lui Brahms, pianul fiind susținut de Rubinstein. [...] Cred că o bucată muzicală își are decorul ei (întotdeauna însă în singurătate), şi un concert public o depersonalizează, o abstractizează, o face să-şi piardă din esenţa magică. Poate din cauza aceasta concertele simfonice sau opera apar vulgare. În lume, măsori fragmentele, combini, critici, faci socoteli. Concertul lui Brahms e făcut să fie cîntat 
pe mare, ritmul temelor imită valurile şi printre note se profilează luna. Reluat la Bucureşti, desigur că-şi va pierde farmecul, şi voi constata chiar că e mediocru (Holban, 1971a: 119-120).

Cea mai frumoasă este, totuşi, muzica mării însăşi, cea din urmă fiind comparată cu o orchestră simfonică: „Feţele mării. Vocile ei. N-am cunoscut obsesie mai constantă. Dacă aş fi poet, aş face o epopee în care n-ar apare nici un om. Numai valurile... Aş înşira o mie de emoţii, şi aici sînt emoţii suprapuse. Orchestră gigantică, cu nenumărate instrumente" (Holban, 1971a: 109).

În Halucinaţii prozatorul stabileşte o legătură strânsă, bazată pe aprecierile lui subiective, între ipostazele mării şi muzica compozitorilor preferaţi:

Asemenea mării de care m-am simţit odată aşa de aproape, Bach ar forma valurile negre, puternice, în ritm egal şi cu rezonanţe profunde. Beethoven, freamătul şi cataclismele. Mozart, apa liniştită care joacă uşurel, glumeţ şi în acelaşi timp melancolic la scânteierile soarelui. Wagner, vijeliile. Chopin, plescăitul lopeţii la razele de lună. Iar Debussy, valurile subţiri şi capricioase, uneori roze, alteori argintate, lunecând pe maluri şi în care îşi înmoaie nimfele degetele de catifea (Holban, 1958: 360).

Paralelismul mare-muzică conţine, în fine, şi o sugestie a morţii, a sfârşitului. Zbaterea neîntreruptă a valurilor însoţită de acordurile simfonice îndreaptă atenţia eroului spre lucrurile esenţiale şi ultime.

\section{BIBLIOGRAFIE}

AlimĂNEȘTEANU, P. (1934): Interviul cu Anton Holban. Reporter, 26: 2.

CĂLINESCU, Al. (1978): Scriitori romîni (mic dicţionar). Bucureşti: Editura ştiinţifică şi enciclopedică.

Holban, A. (1928a): Cu amicul Hans în țara lui d'Aurevilly. Universul literar, 47: 755.

Holban, A. (1928b): Cu amicul Hans în țara lui d'Aurevilly. Universul literar, 49: 786.

Holban, A. (1958): Parada dascălilor. Bucureşti: Editura de Stat pentru literatură şi artă.

Holban, A. (1978): Pseudojurnal. Bucureşti: Editura Minerva.

HolbAN, A. (1971a): Romane, I. Bucureşti: Editura Cartea Românească.

Holban, A. (1971b): Romane, II. Bucureşti: Editura Cartea Românească.

ICHIM, O. (2003): Două motive literare în proza lui Anton Holban: muzica şi marea. Anuar de lingvistică şi istorie literară, XXXIX-XLI: 209-212.

SIMUT, I. (2006): Ceasornicarul sufletului feminin. România Literară, 5 (ediţia electronică). 